\title{
A Computational Model to Estimate the Performance of 8 inches RO Membranes in Pressure Vessel
}

\author{
Ali Altaee*
}

School of Engineering University of the West of Scotland Paisley PA1 2BE, UK

\begin{abstract}
A computational model for estimating RO system performance was developed in this study. Wide range of seawater concentrations $32000 \mathrm{mg} / \mathrm{L}, 35000 \mathrm{mg} / \mathrm{L}, 38000 \mathrm{mg} / \mathrm{L}$, and $43000 \mathrm{mg} / \mathrm{L}$ were used as feed solution. Two different types of Filmtec RO membranes were investigated; SW30HRLE-440i and SW30HR-380. A pressure vessel of four RO elements was simulated in this paper. The recovery rate, ions rejection rate, flow arte, and permeate concentration was simulated for each element in the pressure vessel. The results from this study were compared with Reverse Osmosis System Analysis (ROSA) software assuming that the simulation results from ROSA are reasonably accurate. It was found that the results from this study were in a good agreement with ROSA. The model was also validated against a commercial RO system for seawater desalination, feed concentration $43000 \mathrm{mg} / \mathrm{L}$. An agreement more than $85 \%$ was achieved between the model and the experimental data.
\end{abstract}

Keywords: Reverse osmosis, desalination, RO modeling, pressure vessel.

\section{INTRODUCTION}

Increasing demands on fresh water and depleting natural water resources is one of the major problems which affected most parts of the world [1-3]. Ground and surface water contamination contributed to water shortage problems. Tapping seawater is one way to meet the increasing demands on fresh water $[1,5-6]$. Seawater desalination is widely practiced in arid and water shortage areas for fresh water supply [1, 5-7]. Thermal and $\mathrm{RO}$ technologies are the most common desalination technologies albeit the number of $\mathrm{RO}$ plants exceeded thermal plants worldwide [8-9]. RO process, in fact, requires lower energy than thermal processes and efficiently reliable. 8 inches $R O$ is the most popular membrane for seawater desalination. Nowadays, most of the large $\mathrm{RO}$ desalination plants use 8 inches spiral wound elements in their design. Similarly, the 8 inches low pressure RO is widely used in water reclamation plants.

The objective of present work is to study and estimate the performance RO membranes in the high pressure vessel. This is particularly important in the early stage of $R O$ system design to estimate the permeate flow rate, recovery rate, permeate concentration, and feed pressure of each pressure vessel. A wealth of literature was published in modeling RO membranes but most of it was in studying the performance of a single RO element [10-12]. Many studies investigated the performance of RO system without investigating the performance of each element

*Address corresponding to this author at the School of Engineering University of the West of Scotland Paisley PA1 2BE, UK; Tel: +971507356657; E-mail: alialtaee@hotmail.com in the high pressure vessel $[13,14]$. As explained in the part-one of this study, the performance of RO system has to be evaluated to estimate the number and type of $\mathrm{RO}$ elements required for any new $\mathrm{RO}$ desalination plant. This is particularly important in estimating the initial cost of the RO plant. There is a number of software was developed by membrane manufacturing companies for estimating the performance of $\mathrm{RO}$ system such as ROSA and IMS programme. Unfortunately, such software has a limited applicability as it can only be used with $\mathrm{RO}$ membranes made by the manufacturing company. In the part-one of this study, a model was developed for estimating the performance of RO membrane system which can accommodate any type of $\mathrm{RO}$ membranes. $\mathrm{NaCl}$ was used as a feed solution in part one on the study. The model showed a good agreement with ROSA simulation results [15]. However, in addition to sodium and chloride ions seawater contains other ions such as magnesium, calcium, potassium, sulfate, carbonate in fairly high concentrations $[16,17]$. These ions although exist in lower concentrations than sodium and chloride but they have significant impact on the RO membrane performance [1]. For instance calcium and sulfate ions contribute to the scale problems in the RO membranes $[1,14]$. On the other hand, boron exists in a very low concentration but it has especial importance due to its potential risk on the human health and environment [18]. Further more, it should be noted here that the osmotic pressure of $\mathrm{NaCl}$ solution is different to that of seawater even if the TDS concentration is equal. Finally, it is important to know the concentrations of different ions in the permeate water and how may the concentrations of these ions effect the quality of desalinated water. In this paper the effect of different 
ions in seawater are evaluated. In addition to sodium and chloride ions, sulfate, calcium, potassium, and magnesium ions were considered in the simulation because of their relatively high concentrations in seawater [16, 17]. Four Filmtec RO membranes type SW30HRLE-400i and SW30HR-380 were investigated. The recovery rate, permeate concentration, feed pressure and rejection rate of each element in the pressure vessel was evaluated. Then, the simulation results were compared with ROSA software assuming that ROSA has acceptable marginal errors [15]. The model was also validated against a pilot plant $\mathrm{RO}$ system for seawater desalination, feed concentration $43000 \mathrm{mg} / \mathrm{L}$ [19].

\section{MODEL DEVELOPMENT}

A computational model was developed in this study to estimate the performance of RO membranes in a high pressure vessel. In the present work, seawater was used as a feed solution and the performance of RO membrane system was evaluated accordingly. The concentrations of sodium, chloride, calcium, sulfate, magnesium, and potassium ions in seawater were accounted for in calculating the rejection rate, osmotic pressure, and permeate concentration of the $\mathrm{RO}$ system.

The mathematical equations used this study are listed in Table 1. Additional details about these equations are shown in Figure $\mathbf{1}$ [15]. Table $\mathbf{1}$ equations were used throughout this study in estimating the performance of $\mathrm{RO}$ elements in a high pressure vessel. Pressure drop along the concentrate side of the RO membrane was estimated from the following equation [16]:

$$
P_{c d}=0.01 * n * q_{\text {cave }}^{1.7}
$$

Typically, pressure drop in the concentrate side of seawater RO membranes is about 0.1 bar. The aforementioned equation was developed by Filmtec to estimate the pressure drop in 8 inch diameter seawater RO membrane but it can also be applied to different 8 inch seawater RO membranes since; first membrane companies using almost the same technologies in the manufacturing process. Secondly pressure drop in the concentrate side of $\mathrm{RO}$ is insignificant.

The method of computing the performance of $\mathrm{RO}$ elements in the pressure vessel requires iterative calculations of feed osmotic pressure, recovery rate, and feed pressure of each RO membrane in the vessel. Up to $8 \mathrm{RO}$ elements can be loaded in a signal pressure vessel. However, in small plants a pressure vessel of 6 to 8 elements is used. 4-6 RO elements per pressure vessel was investigated in the current study. Bearing in mind this procedure can be adopted for extended numbers $\mathrm{RO}$ element in the pressure vessel.

\section{RESULTS AND DISCUSSION}

Two different types of seawater Filmtec membranes were investigated in this study, SW30HRLE-400i and

Table 1: Mathematical Equations Applied in The Model Building

\begin{tabular}{|c|c|}
\hline Equation & Application \\
\hline \hline$Q_{p}=A_{m} * A_{w} * F F *\left(P_{f}-\frac{P_{c d}}{2}-P_{p}-\pi_{c a v e}+\pi_{p}\right)$ & Calculate initial flow in RO system \\
\hline$\pi=n_{i} * C * R_{g} * T$ & Calculate osmotic pressure of seawater \\
\hline$C_{f c}=C_{f} * \frac{\ln \frac{1}{1-R}}{R}$ & Calculate average concentrate side feed concentration \\
\hline$C P=E X P(0.7 R)$ & Calculate concentration polarization factor \\
\hline$C_{p}=B * C_{f c} * C P * R j * \frac{A_{m}}{Q_{p}}$ & Calculate permeate concentration \\
\hline$\pi_{p}=\pi_{f} *\left(1-R_{j}\right)$ & Calculate permeate feed pressure \\
\hline$\pi_{c a v e}=\pi_{f} * \frac{C_{f c}}{C_{f}} * C P$ & Calculate average concentrate side osmotic pressure \\
\hline$B=\frac{(1-R j) * J}{R j}$ & Calculate slat diffusion coefficient \\
\hline
\end{tabular}




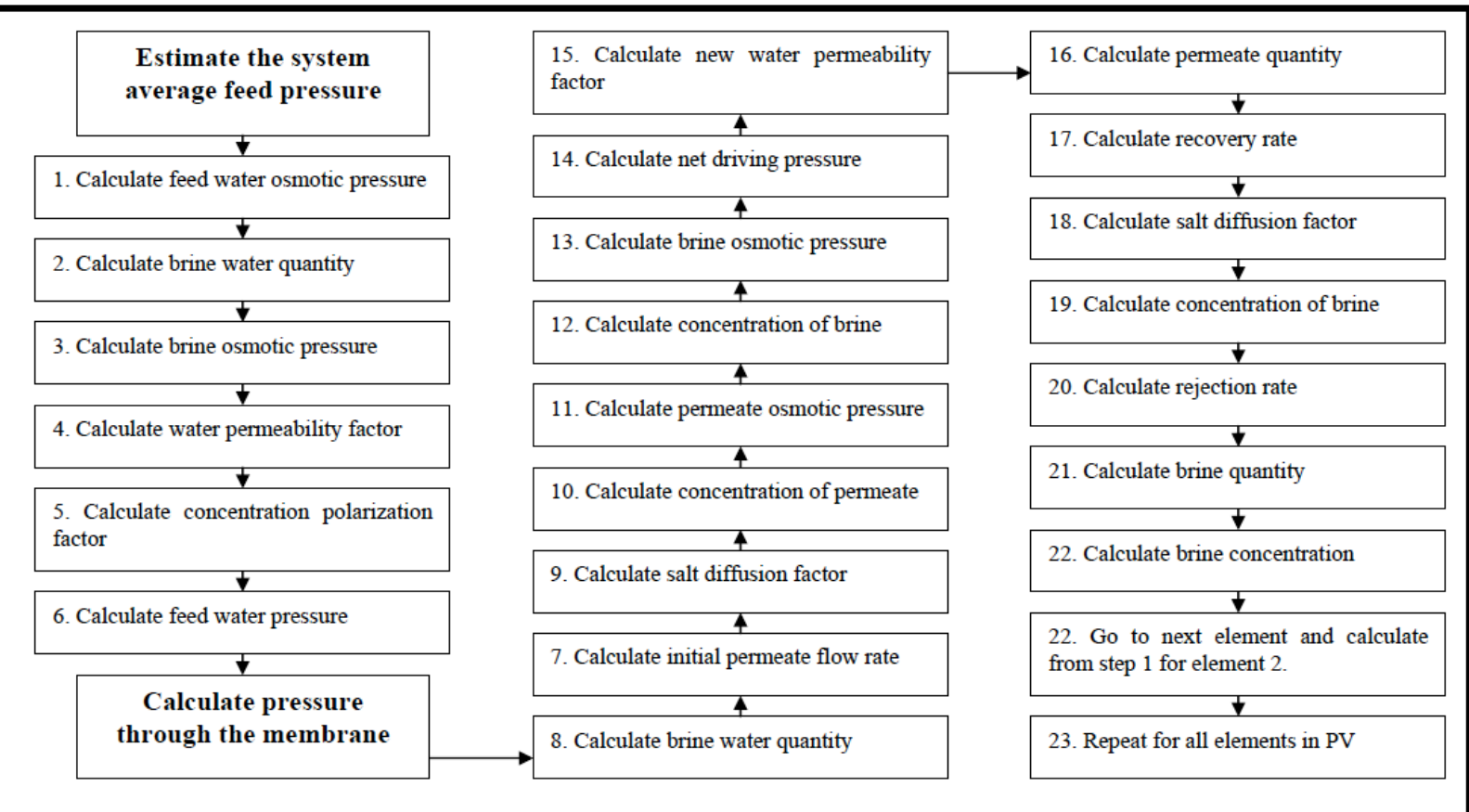

Figure 1: Diagram showing steps followed to compute the membrane performance.

SW30HR-380. The characteristics of these membranes are described in the following sections of this paper. Three different feed concentrations were examined here, $32000 \mathrm{mg} / \mathrm{L}, 35000 \mathrm{mg} / \mathrm{L}$ and $38000 \mathrm{mg} / \mathrm{L}$. Then, data from an $\mathrm{RO}$ pilot plant were used to validate the model in this study.

\subsection{Filmtec RO Membrane SW30HRLE-440i}

Filmtec membrane type SWHRLE-400i was considered in this study for RO system analysis. A pressure vessel contains four RO membrane was under investigation. Dow ${ }^{\mathrm{TM}}$ Filmtec SWHRLE-400i is a high rejection rate and productivity $\mathrm{RO}$ membrane which is suitable for seawater desalination at reasonable cost [16]. The membrane properties can be found on the manufacturing website as well as in the part one of this study [15]. The membrane permeability and salt diffusion were $1.056 \mathrm{~L} / \mathrm{m}^{2}$.h.bar and 0.00189 $\mathrm{m} / \mathrm{d}$ respectively. The total active area of SWHRLE$400 \mathrm{i}$ module is $37.2 \mathrm{~m}^{2}$ and salt rejection rate is $99.75 \%[16]$.

In the current study seawater was used as a feed solution. Two different concentrations were applied to evaluate the performance of RO system [16, 17]. In

Table 2: Seawater Composition [16]

\begin{tabular}{|c|c|c|c|}
\hline lons & Eastern Mediterranean $(38000 \mathrm{mg} / \mathrm{L})$ & Standard Seawater $(35000 \mathrm{mg} / \mathrm{L})$ & Standard Seawater $(32000 \mathrm{mg} / \mathrm{L})$ \\
\hline $\mathrm{Cl}^{-}$ & 21200 & 19406 & 17737 \\
\hline $\mathrm{SO}_{4}{ }^{2-}$ & 2950 & 2710 & 2477 \\
\hline $\mathrm{Mg}^{2+}$ & 1403 & 1182 & 1182 \\
\hline $\mathrm{Ca}^{2+}$ & 423 & 421 & 385 \\
\hline $\mathrm{Br}-$ & 155 & - & \\
\hline $\mathrm{BO}_{3}{ }^{3-}$ & 72 & - & \\
\hline$r^{-}$ & 2 & - & \\
\hline
\end{tabular}


case one, seawater concentration was $35000 \mathrm{mg} / \mathrm{L}$ which represents typical seawater. Whilst in case two, the concentration of feed water was increased to 38000 $\mathrm{mg} / \mathrm{L}$ to represents Eastern Mediterranean seawater [17]. The composition of seawater in both concentrations is listed in Table 2. In addition to the sodium and chloride ions, seawater contains calcium, magnesium, potassium, sulfate, boron, silicon, bicarbonate, bromide and carbonate. Also there are other ions which exist in a trace concentration such as nitrate, fluoride, ion and manganese and will not be considered in this study [16, 17]. The major ions of concern in this study are $\mathrm{Na}, \mathrm{Cl}, \mathrm{Mg}, \mathrm{Ca}$, and $\mathrm{SO}_{4}$ due to their high concentration in seawater and impact on the RO desalination process [18]. The simulation conditions of both seawater salinities (i.e. $35000 \mathrm{mg} / \mathrm{L}$ and $38000 \mathrm{mg} / \mathrm{L}$ ) were as following; feed water flow rate $4 \mathrm{~m}^{3} / \mathrm{h}$, recovery rate $30 \%$, feed temperature $25{ }^{\circ} \mathrm{C}$ and feed water $\mathrm{pH} 7.6$.

The simulation results from the model in this paper were compared with ROSA. Recovery rate, permeate concentration, permeate flow rate, and feed pressure of each element in the pressure vessel were calculated. The simulation results showed that the elements flow rates from this study were very close to those from ROSA (Figure 2). The flow rate decreased from the head to the tail element which was due to the higher osmotic pressure of the feed solution. Similarly, the recovery rates from both models were very close (Figure 3). The total recovery rates of the RO system from ROSA and this study were equal; $1.2 \mathrm{~m}^{3} / \mathrm{h}$. In

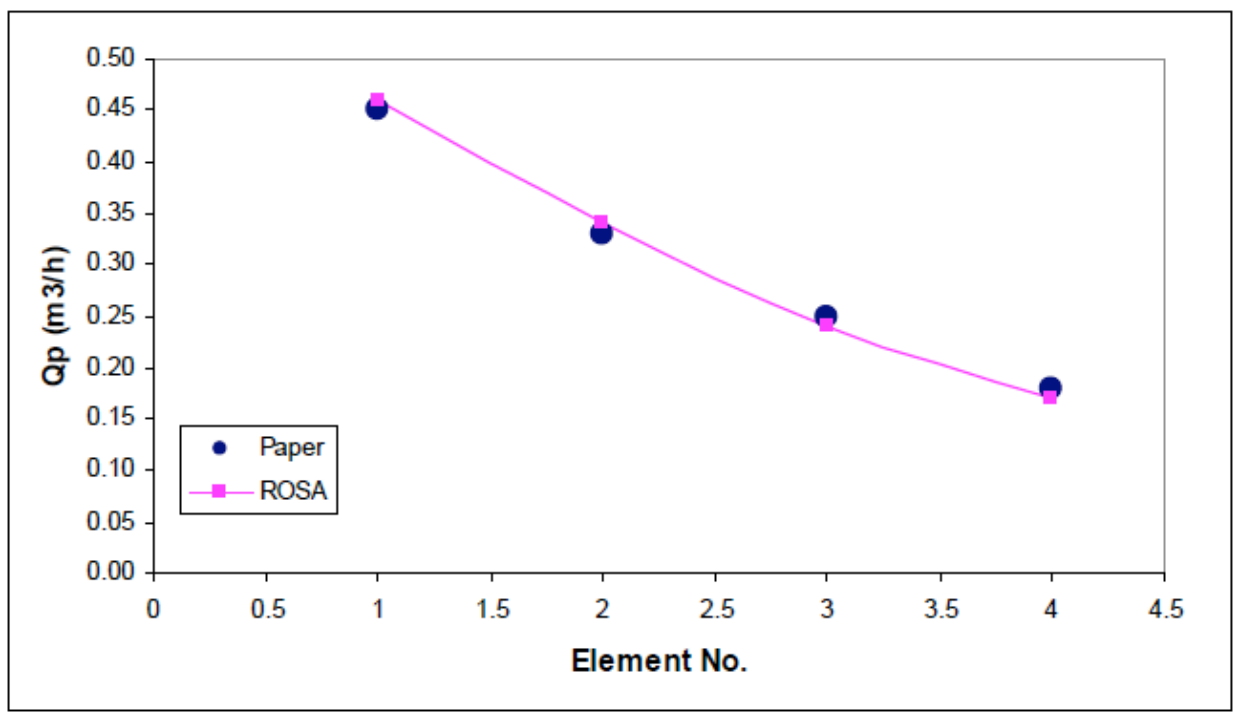

a

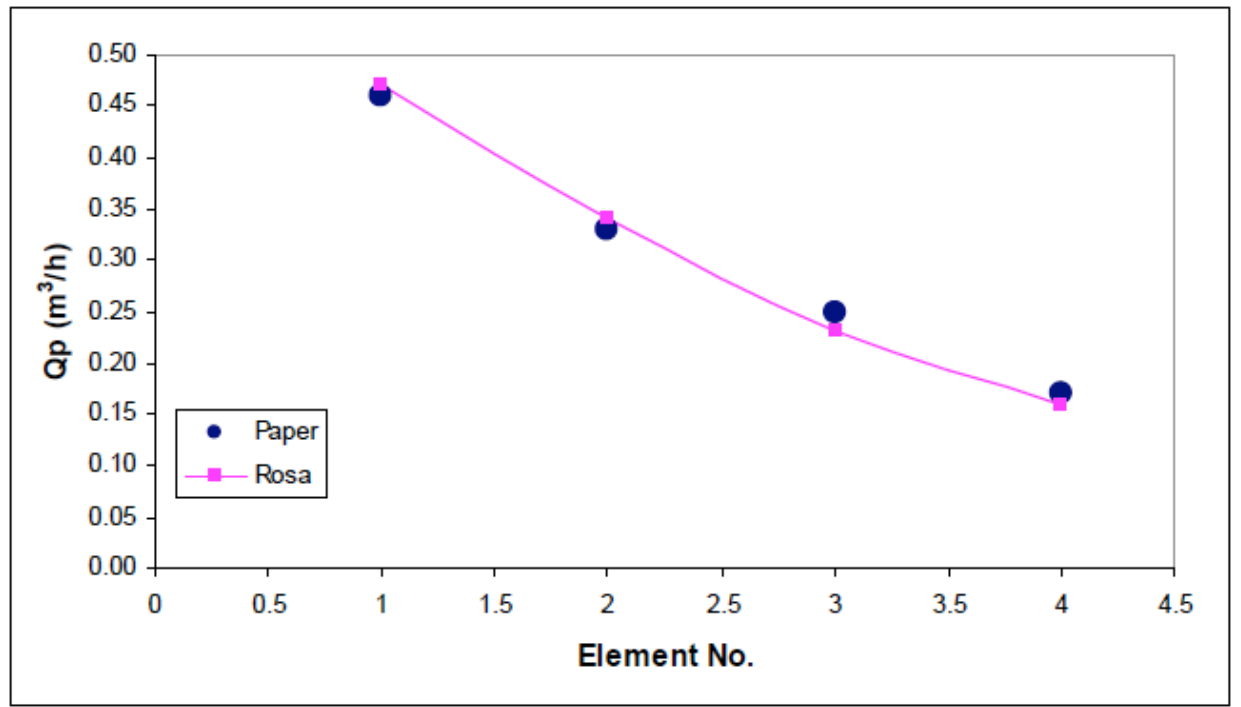

$\mathrm{b}$

Figure 2: Permeate flow of each element in the RO system. a) feed water $35000 \mathrm{mg} / \mathrm{L}$. b) Feed water $38000 \mathrm{mg} / \mathrm{L}$. 


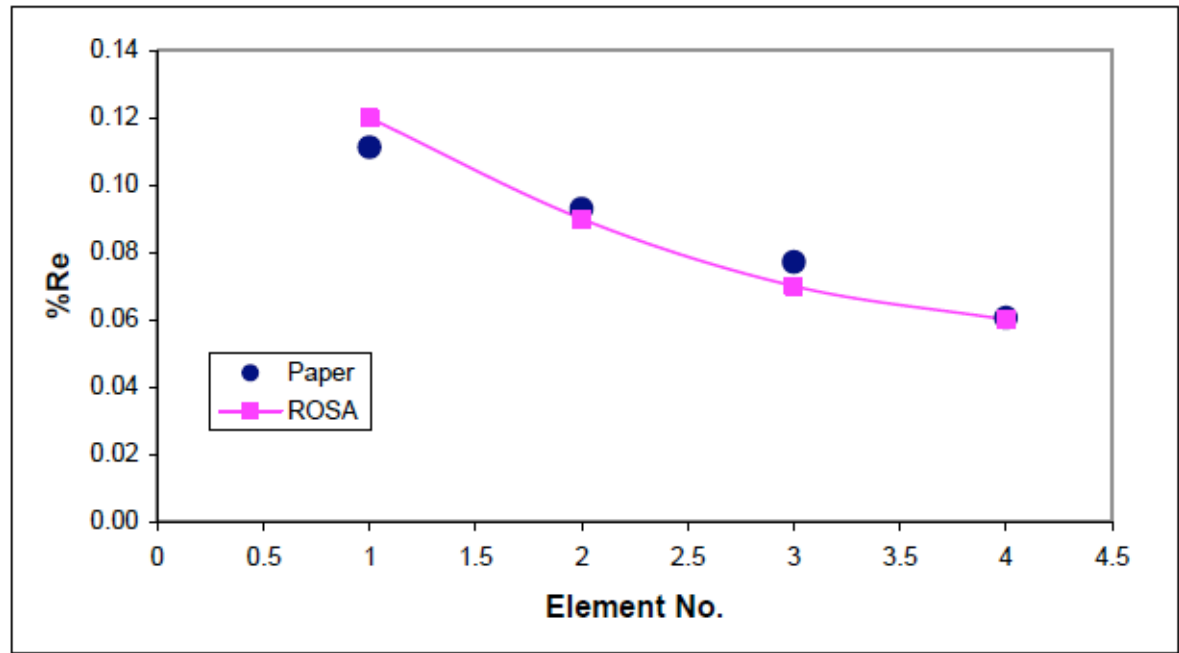

a

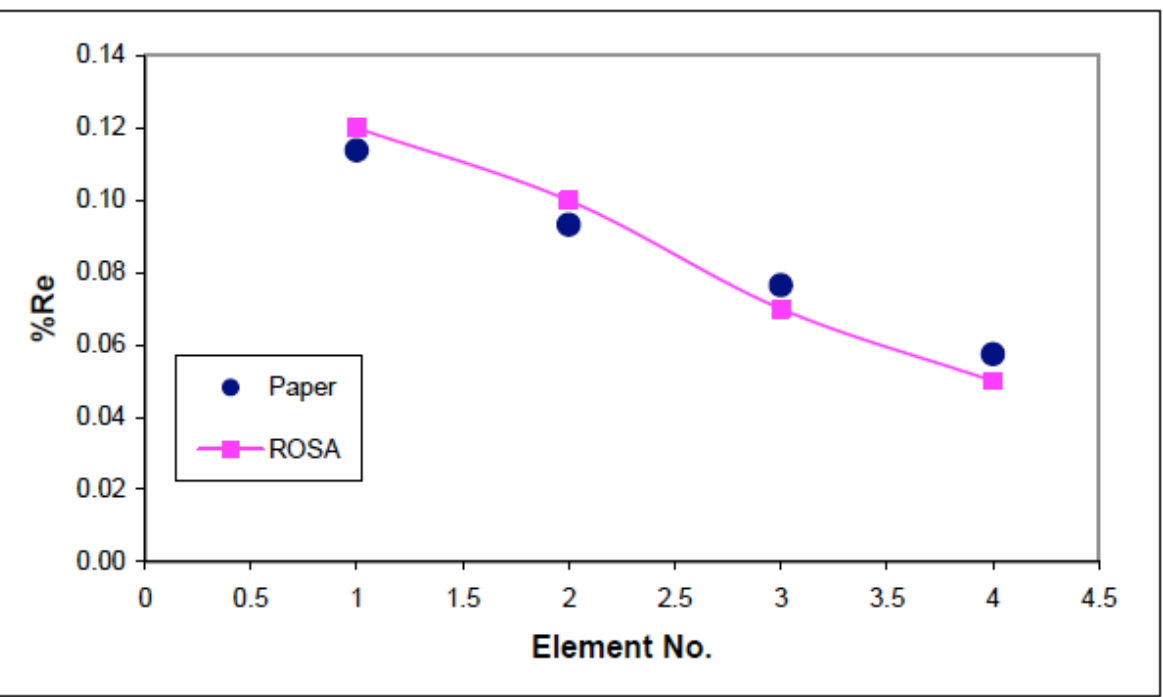

b

Figure 3: Recovery rate of each element in the RO system. a) Feed water TDS $35000 \mathrm{mg} / \mathrm{L}$. b) Feed water TDS $38000 \mathrm{mg} / \mathrm{L}$.

case of feed pressure, although there was more than $98 \%$ agreement between the two models, the feed pressure in this study was slightly higher than ROSA (Figure 4). This was probably due to the slightly higher osmotic pressure calculated in the present work. However, the differences in feed pressure between the two models were insignificant. On the other hand, the concentrations of permeate from both models were also compared. As illustrated in Figure 5, there was a good agreement between the two models and for both feed water concentrations, i.e. $35000 \mathrm{mg} / \mathrm{L}$ and 38000 $\mathrm{mg} / \mathrm{L}$. The overall agreement between this study and ROSA was more than $90 \%$.

\subsection{Filmtec RO Membrane SW30HR-380}

A pressure vessel consists of four RO membranes type SW30 HR-380 was investigated here. Dow ${ }^{\mathrm{TM}}$
Filmtec SW30HR-380 exhibits a high performance and salt rejection which makes it suitable for seawater desalination [16]. The membrane properties can be found on the manufacturing website [16]. The membrane permeability and salt diffusion were 0.917 $\mathrm{L} / \mathrm{m}^{2}$.h.bar and $0.00197 \mathrm{~m} / \mathrm{d}$ respectively. The total active area of SW30HR-380 module is $35 \mathrm{~m}^{2}$ and salt rejection rate is $99.7 \%$.

A feed water concentration equal to $32000 \mathrm{mg} / \mathrm{L}$ was investigated here to estimate the performance of RO membrane system. The composition of seawater is shown in Table 2. The main ions in feed water are sodium, chloride, calcium, magnesium, potassium, sulfate, silicon, bicarbonate, bromide and carbonate. The simulation conditions were as following: $4 \mathrm{~m}^{3} / \mathrm{h}$ feed water flow rate, $30 \%$ recovery rate, feed temperature $25^{\circ} \mathrm{C}$ and feed water $\mathrm{pH}$ 7.6. 


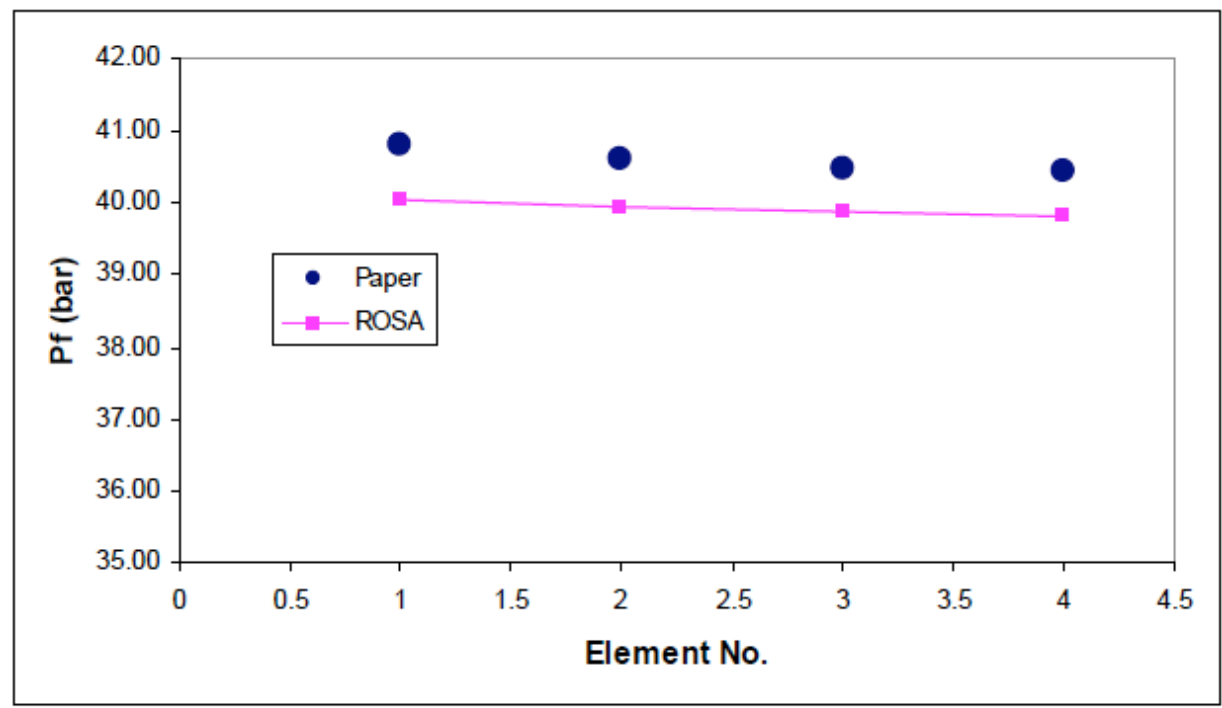

a

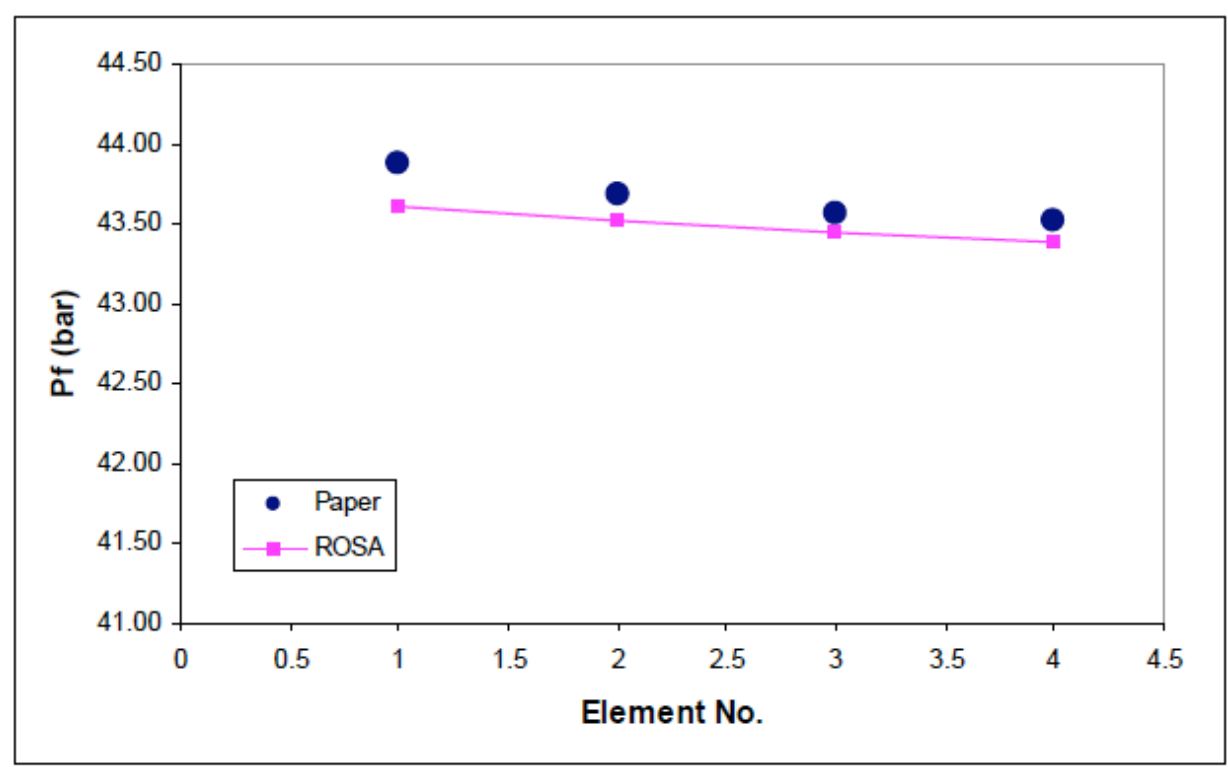

$\mathrm{b}$

Figure 4: Feed pressure of each element in the RO system. a) Feed water TDS $35000 \mathrm{mg} / \mathrm{L}$. b) Feed water TDS $38000 \mathrm{mg} / \mathrm{L}$.

Recovery rate, permeate concentration, permeate flow rate, and feed pressure of each element in the pressure vessel was compared with ROSA. A good agreement was identified between the two models. More than $95 \%$ of the permeate flow rates from this study agreed with ROSA results (Figure 6). Similarly, a good agreement was observed between the recovery rates of this study and ROSA (Figure 7). In both models, the recovery and flow rates decreased from first to last $\mathrm{RO}$ element in the high pressure vessel due to increasing the osmotic pressure of feed solution. Regarding feed pressure, it was noticed to be slightly higher in this study compared to ROSA (Figure 8). This insignificant difference was due to the slightly higher feed osmotic pressure in this study compared to
ROSA; 23.52 bar compared to 22.67 bar respectively. Finally, the permeate concentration from this study was compared with ROSA (Figure 9). The results showed a insignificant difference between the study and ROSA; $534 \mathrm{mg} / \mathrm{L}$ and $490 \mathrm{mg} / \mathrm{L}$ respectively. An average agreement over $95 \%$ was achieved between ROSA and this paper which indicated the reliability of the model here in estimating the performance of $\mathrm{RO}$ system.

\subsection{Experimental Data from SWRO Plant}

The model was also validated against experimental data from SWRO membrane system for seawater desalination in the Red Sea. More information about the SWRO plant can be found in the literature [19]. 


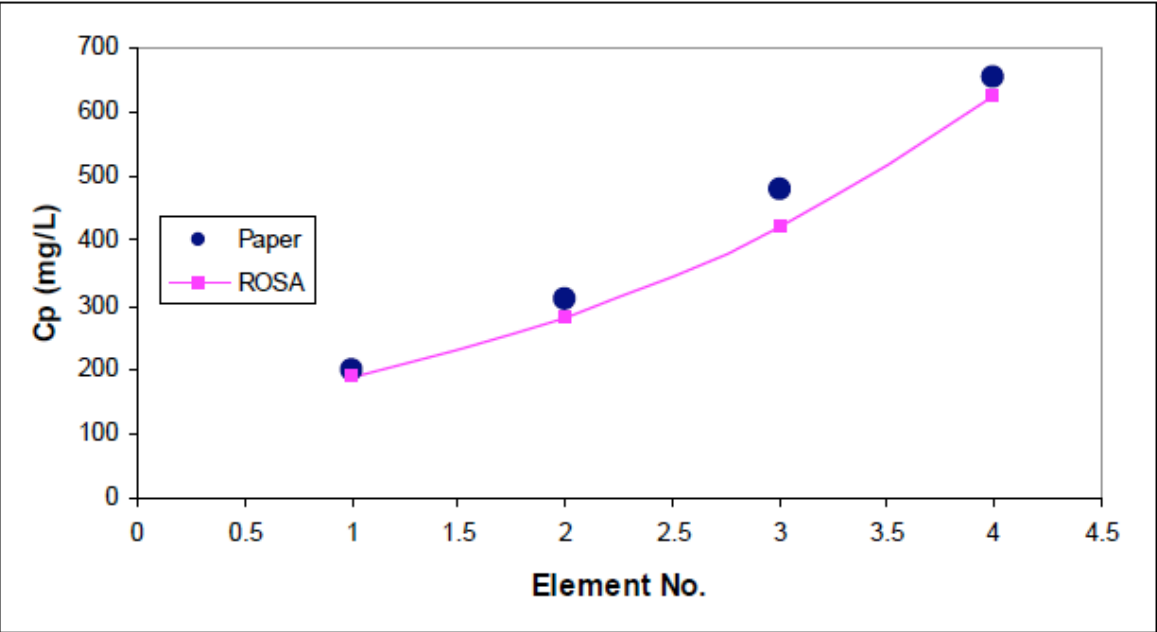

a

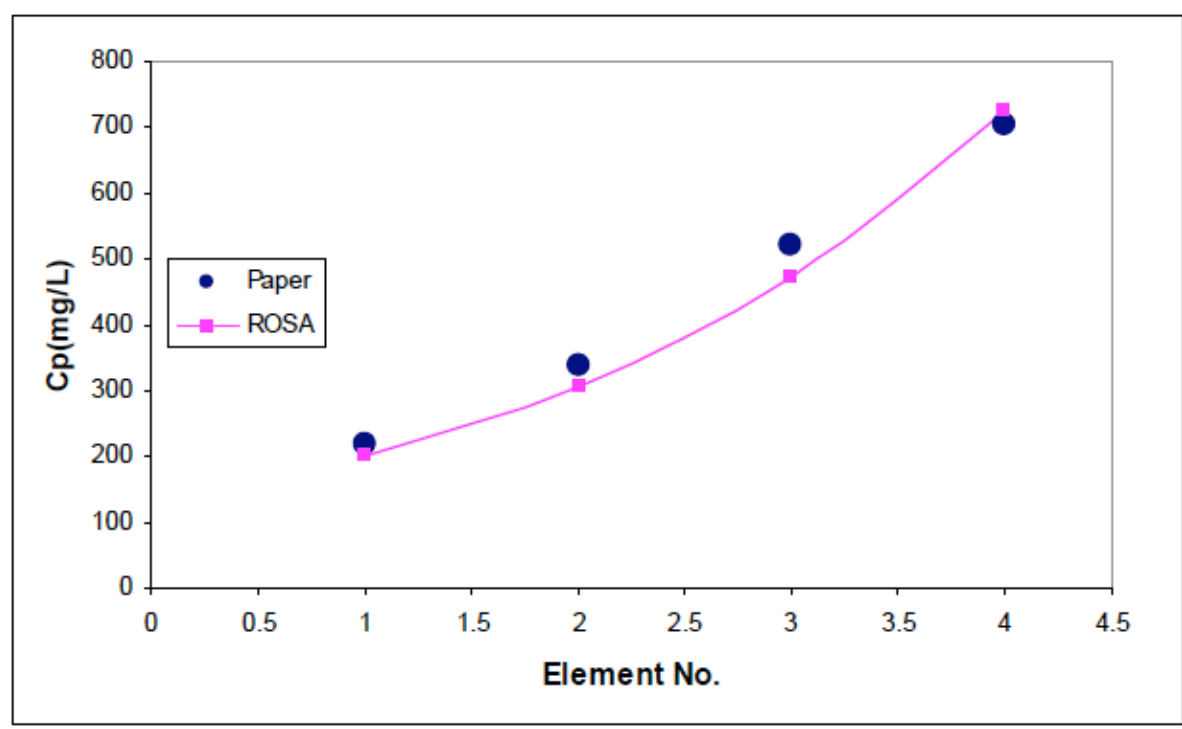

$\mathrm{b}$

Figure 5: Permeate concentration of each element in the RO system. a) Feed water TDS $35000 \mathrm{mg} / \mathrm{L}$. b) Feed water TDS $38000 \mathrm{mg} / \mathrm{L}$.

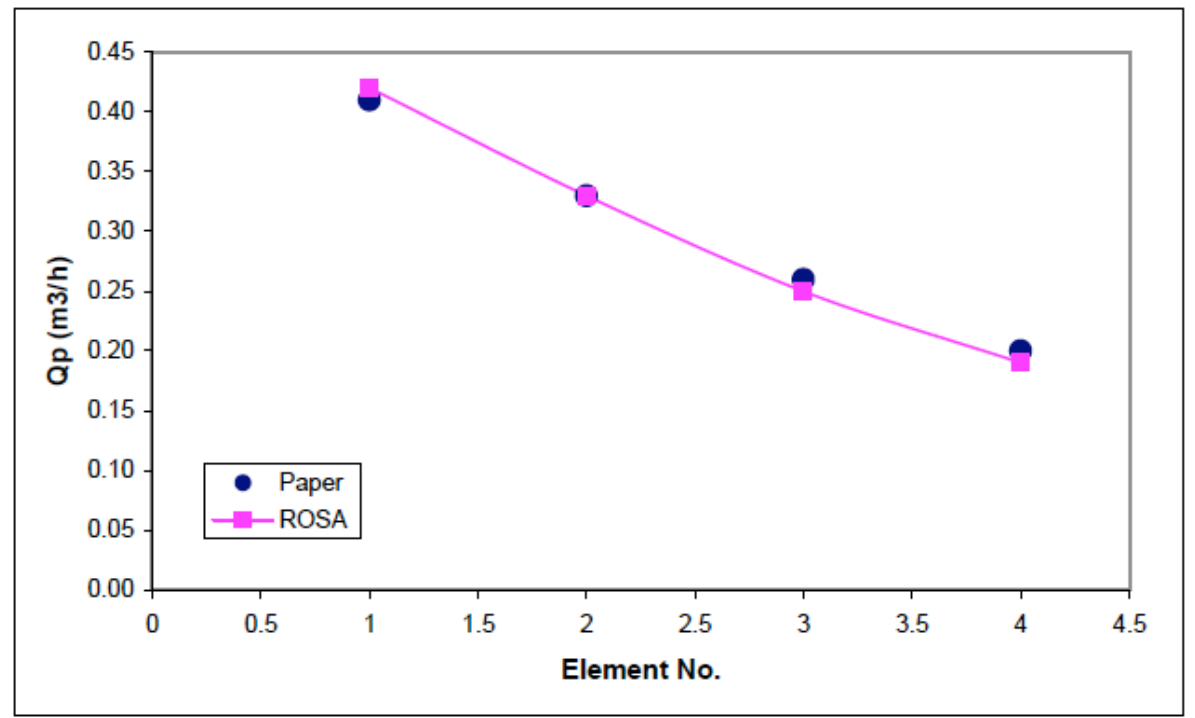

Figure 6: Permeate flow of each element in the RO system. 


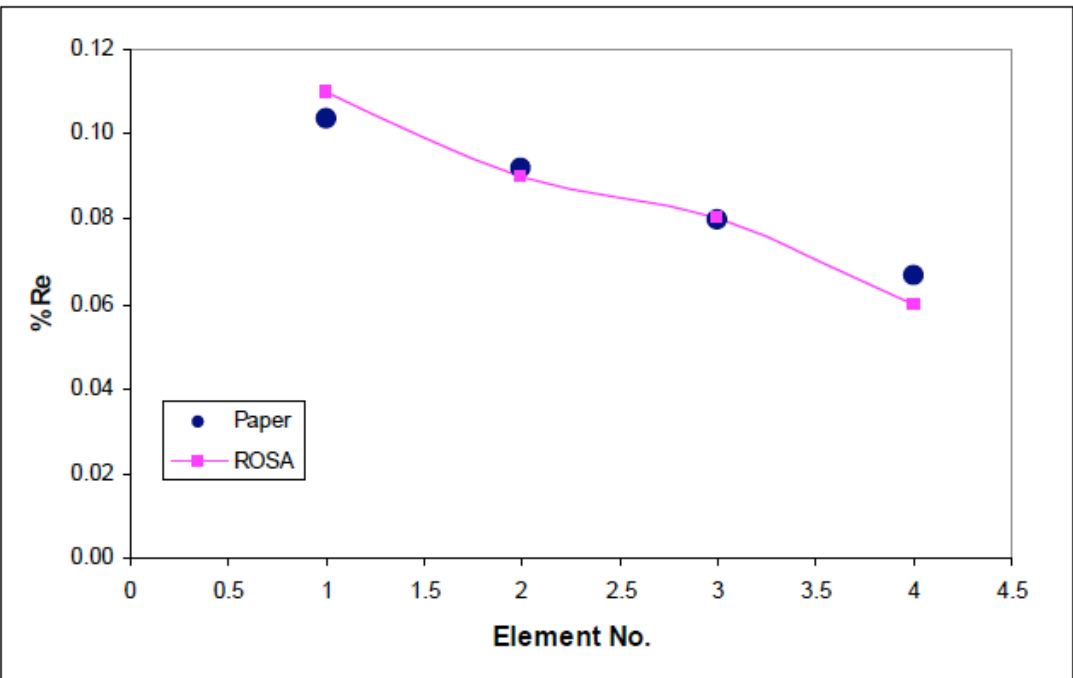

Figure 7: Recovery rate of each element in the RO system.

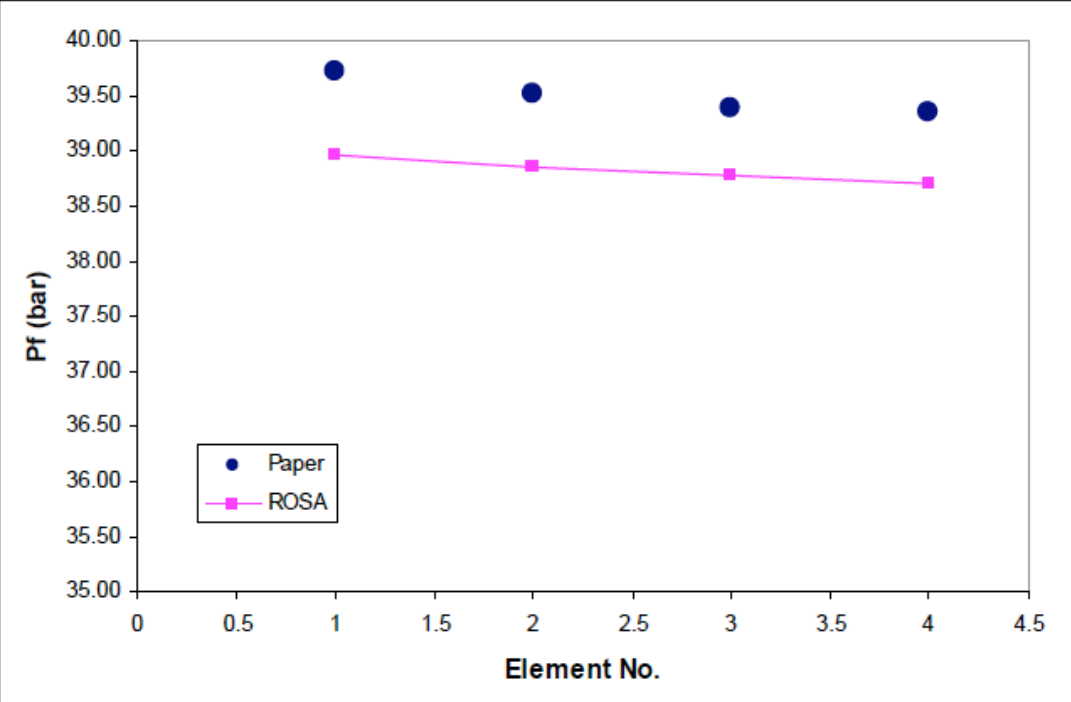

Figure 8: Feed pressure of each element in the RO system.

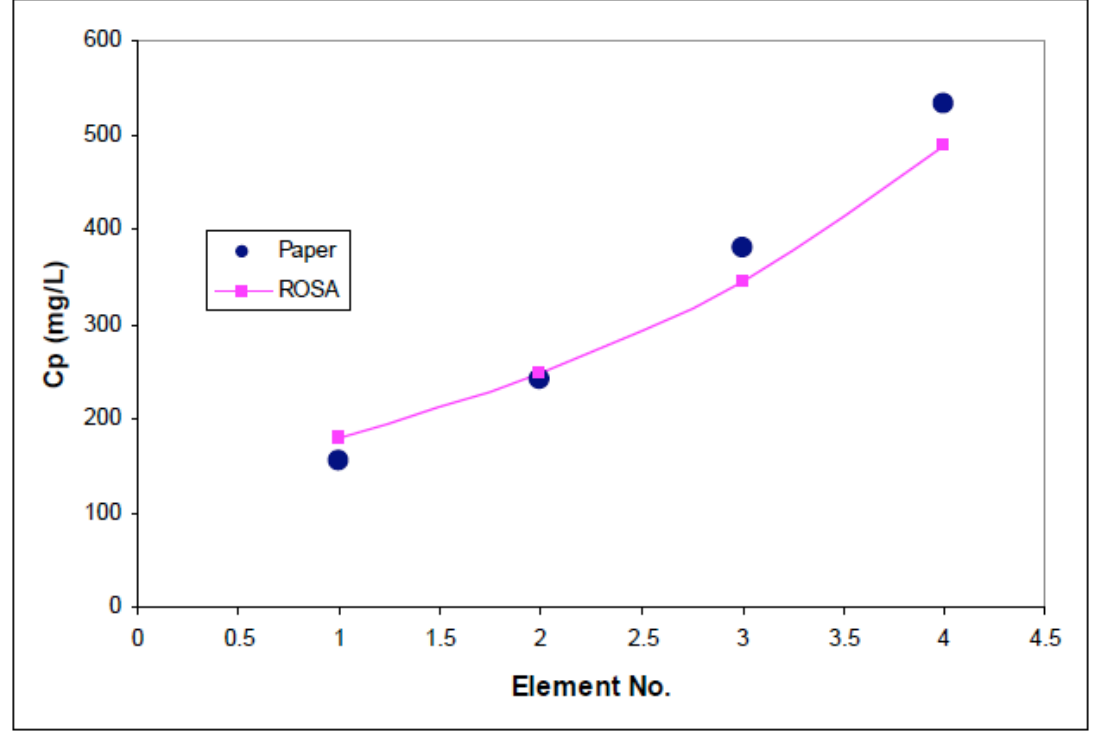

Figure 9: Permeate concentration of each element in the RO system. 
Table 3: SWRO Membrane Specifications [17]

\begin{tabular}{|c|c|}
\hline Parameter & Value \\
\hline \hline Membrane length & 40 inch $(101.6 \mathrm{~cm})$ \\
\hline Membrane width & 8 inch $(20.32 \mathrm{~cm})$ \\
\hline Membrane area & $300 \mathrm{ft}^{2}\left(27.9 \mathrm{~m}^{2}\right)$ \\
\hline Design rejection & $99.4 \%$ \\
\hline Design permeate flow rate & $5000 \mathrm{US} \mathrm{gpm}\left(19.0 \mathrm{~m}^{3} / \mathrm{d}\right)$ \\
\hline Maximum operating pressure & $1000 \mathrm{psi}(69 \mathrm{bar})$ \\
\hline Allowable operating-cleaning pH range & $4-11,2.5-11$ \\
\hline Allowable feed water temperature & 1 to $45^{\circ} \mathrm{C}$ \\
\hline
\end{tabular}

Testing condition: $32800 \mathrm{mg} / \mathrm{L} \mathrm{NaCl}, 55.2$ bar, $7 \%$ recovery, $25^{\circ} \mathrm{C}$ and $\mathrm{pH} 5.7$.

Each pressure vessel in the plant contains 6 spiral wound SWRO membranes. The specifications of RO membranes are shown in Table $\mathbf{3}$.

From the experimental data, water permeability and salt diffusion coefficient were calculated as following:

$$
\begin{gathered}
A_{w}=0.964 \mathrm{~L} / \mathrm{m}^{2} \cdot h \cdot \mathrm{bar} \\
B=0.0041 \mathrm{~m} / \mathrm{d}
\end{gathered}
$$

The feed flow and recovery rate of the RO system were, respectively, $9.6 \mathrm{~m}^{3} / \mathrm{h}$ and $30 \%$. These data were used in this study to investigate its efficiency in predicting the performance of RO membrane system. A strong agreement was found between this study and the experimental data (Table 4). For permeate TDS, an agreement over $80 \%$ was achieved between the experimental data and this study; $451 \mathrm{mg} / \mathrm{L}$ compared to $506 \mathrm{mg} / \mathrm{L}$ respectively. The permeate TDS increased from the head to the tail element in the pressure vessel as shown in Table 5. Additionally, permeate flow, recovery rate and permeate concentration of each $\mathrm{RO}$ elements in the pressure vessel were calculated and the total values of these parameters were compared with the pilot plant data (Table 5). Once again, a good agreement was found between the two them (Figure 10). As expected the permeate TDS increased from head to tail element while the recover rate and permeate flow decreased from the head to the tail RO element. A comparison between the pilot plant data and the results from this study shows the reliability of the model in estimating the performance of the RO system.

\section{CONCLUSION}

The performance of $\mathrm{RO}$ system was estimated using a computational model. The model was

Table 4: Comparison Between the Results from SWRO Plant and the Study

\begin{tabular}{|c|c|c|c|}
\hline \multirow{2}{*}{ Parameter } & \multicolumn{2}{|c|}{ Experimental Data } & Model \\
\cline { 2 - 4 } & Feed & Product & 5 \\
\hline \hline $\mathrm{Ca}$ & 550 & 4 & 15 \\
\hline $\mathrm{Mg}$ & 1570 & 140 & 179 \\
\hline $\mathrm{Na}$ & 13000 & 10 & 12 \\
\hline $\mathrm{CO}_{3}$ & 800 & 3 & - \\
\hline $\mathrm{HCO}_{3}$ & 1 & 40 & - \\
\hline $\mathrm{SO}_{4}$ & 135 & 2 & 3.4 \\
\hline $\mathrm{Cl}^{\mathrm{NO}}{ }_{3}$ & 3700 & 240 & 291 \\
\hline $\mathrm{F}$ & 23370 & - & - \\
\hline $\mathrm{TDS}$ & 1.6 & - & - \\
\hline Recovery rate & 2.5 & 451 & 506 \\
\hline Permeate flow rate $\mathrm{m}^{3} / \mathrm{h}$ & 43130 & $30 \%$ & $30 \%$ \\
\hline No of elements/vessel & - & 2.88 & 2.88 \\
\hline
\end{tabular}


Table 5: Distribution of Permeate Flow, Recovery Rate and Permeate TDS Through the Pressure Vessel

\begin{tabular}{|c|c|c|c|c|c|c|c|c|c|}
\hline Parameter & Feed & \multicolumn{6}{|c|}{ Element Number } & Model Total & Exp. Data \\
\hline Qp m3/h & 9.6 & 0.63 & 0.54 & 0.5 & 0.45 & 0.4 & 0.36 & 2.88 & 2.88 \\
\hline$\% \operatorname{Re}$ & 30 & 0.07 & 0.06 & 0.06 & 0.06 & 0.05 & 0.05 & 0.3 & 0.3 \\
\hline Cp mg/L & 43130 & 173 & 264 & 412 & 605 & 836 & 1091 & 506 & 451 \\
\hline
\end{tabular}

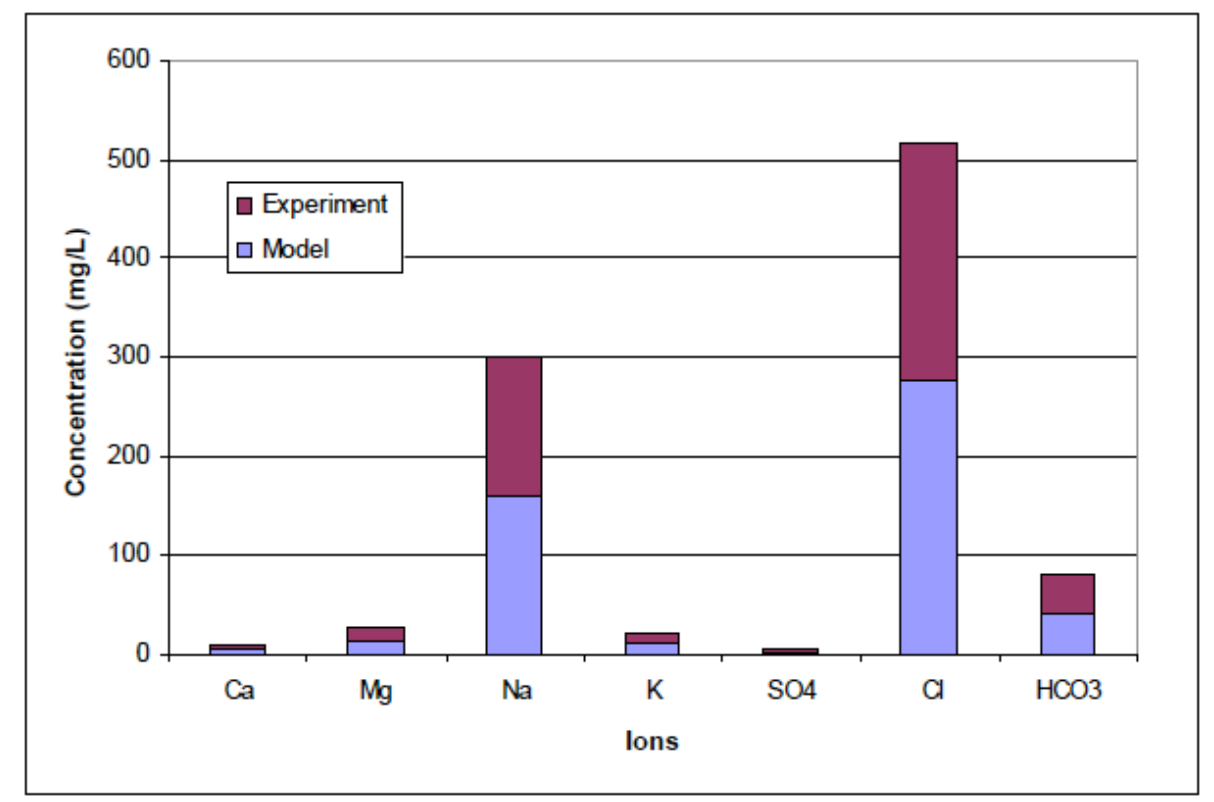

Figure 10: Comparison between experimental and the model seawater ions concentration.

developed to predict the performance of $\mathrm{RO}$ membrane using different seawater concentrations. The results from the study were compared with ROSA assuming that ROSA results are fairly accurate [15]. In this study, two types of Filmtec RO membranes were investigated using wide rage of seawater concentrations; 32000 $\mathrm{mg} / \mathrm{L}, 35000 \mathrm{mg} / \mathrm{L}, 38000 \mathrm{mg} / \mathrm{L}$, and $43000 \mathrm{mg} / \mathrm{L}$. Recovery rate, permeate flow, permeate flow, and permeate concentration of each element in the pressure vessel was compared with ROSA (Figures 1 to 9). The simulation results showed a good agreement between this study and ROSA. For all feed concentrations, the results from this study were consistently comparable to ROSA. Then, the model was tested against pilot plant data for seawater desalination; feed salinity $43000 \mathrm{mg} / \mathrm{L}$. There was a good agreement between the study and the pilot plant results as shown in Tables $\mathbf{4}$ and $\mathbf{5}$. In conclusion, the study presented a computational model which was able to generate a reproducible data and can reliably be used for estimating the performance of RO system regardless the type of $\mathrm{RO}$ membrane or feed water salinity.
In contrast to the commercial RO models, the model in this study is open source and can readily be coupled with any other software used in the design of posttreatment and/or pretreatment processes of $\mathrm{RO}$ desalination plant. It should be noted here that results obtained from the model here would be slightly different to the experimental data due to errors from calculating the actual solution concentration at the membrane surface, membrane compaction, and membrane fouling. However, the expected uncertainties of the model is quiet reasonable and within acceptable range.

\section{ACKNOWLEDGEMENT}

The author would like acknowledge the contribution of Dr Hugh Fergusson and Dr Corrado which assisted in publishing this work.

\section{NOMENCLATURE}

$$
\begin{aligned}
& A C F=\text { average concentration factor } \\
& A m=\text { membrane area } \mathrm{m}^{2}
\end{aligned}
$$




$$
\begin{aligned}
& A_{w} \quad=\text { water permeability constant } \mathrm{L} / \mathrm{m}^{2} \cdot \mathrm{h} \cdot \text { bar } \\
& B=\text { salt permeability constant } \mathrm{m} / \text { day } \\
& \text { C = concentration } \mathrm{mg} / \mathrm{L} \\
& C_{b} \quad=\text { bulk concentration } \mathrm{mg} / \mathrm{L} \\
& C_{f} \quad=\text { feed concentration } \mathrm{mg} / \mathrm{L} \\
& C_{f c}=\text { concentrate feed concentration } \mathrm{mg} / \mathrm{L} \\
& C P=\text { concentration polarization factor } \\
& C_{p} \quad=\text { permeate concentration } \mathrm{mg} / \mathrm{L} \\
& C_{w}=\text { concentration at the membrane surface } \mathrm{mg} / \mathrm{L} \\
& F F \quad=\text { fouling factor average concentrate side flow } \\
& \text { rate } \\
& J \quad=\text { water flux } \mathrm{L} / \mathrm{m}^{2} \cdot \mathrm{h} \\
& n_{i} \quad=\text { number of moles of species } \mathrm{i} \\
& n \quad=\text { number of } \mathrm{RO} \text { elements in series } \\
& P_{c d} \quad=\text { concentrate side pressure drop bar } \\
& \Delta P \quad=\text { membrane pressure gradient bar } \\
& Q_{c} \quad=\text { concentrate flow rate } \mathrm{m}^{3} / \mathrm{h} \\
& Q_{f} \quad=\text { feed flow rate } \mathrm{m}^{3} / \mathrm{h} \\
& Q_{p} \quad=\text { permeate flow rate } \mathrm{m}^{3} / \mathrm{h} \\
& q_{\text {cave }}=\text { average concentrate side flow rate } \mathrm{m}^{3} / \mathrm{h} \\
& R \quad=\text { recovery rate } \\
& R_{g} \quad=\text { universal gas constant } 0.082 \mathrm{~kg} \cdot \mathrm{m}^{2} / \mathrm{h}^{2} \cdot \mathrm{k} \\
& R j=\text { membrane rejection rate } \\
& T \quad=\text { feed temperature }{ }^{\circ} \mathrm{C} \\
& \text { TCF = temperature correction factor } \\
& \Delta \pi \quad=\text { osmotic pressure gradient bar } \\
& \pi_{\text {cave }}=\text { average concentrate side osmotic pressure } \\
& \pi_{f} \quad=\text { feed osmotic pressure bar } \\
& \pi_{p} \quad=\text { permeate osmotic pressure bar }
\end{aligned}
$$

\section{REFERENCES}

[1] Fritzmann C, Löwenberg J, Wintgens T, Melin T. State-ofthe-art of reverse osmosis desalination. Desalination 2007; 216: 1-76.

http://dx.doi.org/10.1016/j.desal.2006.12.009

[2] Karagiannis IC, Soldatos PG. Water desalination cost literature: review and assessment. Desalination 2008; 223: 448-56. http://dx.doi.org/10.1016/j.desal.2007.02.071

[3] Peñate B, García-Rodríguez L. Current trends and future prospects in the design of seawater reverse osmosis desalination technology. Desalination 2012; 284: 1-8. http://dx.doi.org/10.1016/j.desal.2011.09.010

[4] Bessenasse M, Kettab A, Moulla AS. Seawater desalination: Study of three coastal stations in Algiers region. Desalination 2010; 250: 423-27. http://dx.doi.org/10.1016/..desal.2009.09.069

[5] Charcosset C. A review of membrane processes and renewable energies for desalination. Desalination 2009; 245: 214-31. http://dx.doi.org/10.1016/j.desal.2008.06.020

[6] El-Zanati E, El-Khatib KM. Integrated membrane -based desalination system. Desalination 2007; 205: 15-25. http://dx.doi.org/10.1016/j.desal.2006.03.548

[7] Gálvez JB, García-Rodríguez L, Martín-Mateos I. Seawater desalination by an innovative solar-powered membrane distillation system: the MEDESOL project. Desalination, 2009; 246: 567-76. http://dx.doi.org/10.1016/j.desal.2008.12.005

[8] Hamed OA. Overview of hybrid desalination systems current status and future prospects. Desalination 2005; 186: 207-14. http://dx.doi.org/10.1016/j.desal.2005.03.095

[9] Al-Sofi MA-K. Seawater desalination - SWCC experience and vision. Desalination 2001; 135: 121-39. http://dx.doi.org/10.1016/S0011-9164(01)00145-X

[10] Jamal K, Khan MA, Kamil M. Mathematical modeling of reverse osmosis systems. Desalination 2004; 160: 29-42. http://dx.doi.org/10.1016/S0011-9164(04)90015-X

[11] Mehdizadeh H, Molaiee-Nejad KH, Chong YC. Modeling of mass transport of aqueous solutions of multi-solute organics through reverse osmosis membranes in case of solutemembrane affinity: Part 1. Model development and simulation. J Membr Sci 2005; 267: 27-40. http://dx.doi.org/10.1016/j.memsci.2005.03.059

Gozálvez JM, Lora J, Mendoza JA, Sancho M. Modeling of a low-pressure reverse osmosis system with concentrate recirculation to obtain high recovery levels. Desalination 2002; 144: 341-45. http://dx.doi.org/10.1016/S0011-9164(02)00341-7

[13] Kahdim AS, Ismail S, Jassim AA. Modeling of reverse osmosis systems. Desalination 2003; 158: 323-29. http://dx.doi.org/10.1016/S0011-9164(03)00471-5

[14] Kim YM, Kim SJ, Kim YS, Lee S, Kim IS, Kim JH. Overview of systems engineering approaches for a large-scale seawater desalination plant with a reverse osmosis network. Desalination 2008; 238: 312-32.

[15] Altaee A. Computational Model for Estimating Reverse Osmosis System Design and performance: Part-One Binary Feed Solution. Desalination 2012; 291: 101-105. http://dx.doi.org/10.1016/j.desal.2012.01.028

[16] Seawater water composition [homepage on the internet]. Lenntech; cited 2012 February 20]: Available from: http://www.lenntech.com/composition-seawater.htm

[17] RO membrane products [homepage of the internet]. Dow Fimtech website; cited 2012 may 5]: Available from: http://www.dowwaterandprocess.com/products/ronf.htm 
[18] Hilal N, Kim GJ, Somerfield C. Boron removal from saline water: A comprehensive review. Desalination 2011; 273: 23-

35.

http://dx.doi.org/10.1016/i.desal.2010.05.012
[19] Tolba AM, Mohamed RA. Performance and characteristics of reverse osmosis membranes. In: Proc $4^{\text {th }}$ International Water Technology Conference; 1999: Alexandria: Egypt 1999; pp. 171-81.

Received on 16-08-2012

Accepted on 15-09-2012

Published on 04-10-2012

DOI: http://dx.doi.org/10.6000/1929-6037.2012.01.01.8 